\title{
Nutritional and Fatty Acid Profile of Human Milk Samples from District Malakand, Pakistan
}

\author{
Muhammad Adil ${ }^{1}$, Kashmala Majid ${ }^{1}$, Kashif Gul ${ }^{1}$, Zawar Hussain ${ }^{1}$, \\ Inayatur Rahman ${ }^{2}$, Muhammad Iqbal Khan ${ }^{1}$ and Murad Ali Khan*1. \\ ${ }^{1}$ Department of Chemistry, Kohat University of Science and Technology, Kohat 26000, Pakistan \\ ${ }^{2}$ Medicinal Botanic Centre, PCSIR Labs Complex, Peshawar-25120, Pakistan. \\ *Corresponding Author Email: drmalikhan@yahoo.com \\ Received 13 February 2020, Revised 01 December 2020, Accepted 04 December 2020
}

\begin{abstract}
Generally, breast milk is the first and complete diet for an infant. It has a pivotal role in determining the growth pattern of the kids. Breast milk has various nutritional ingredients and is a source of energy for the infants. It has a vital role in the development of the immune system. The composition of milk varies with the diet of the mother, environment, and time of feeding. The fatty acid profile and nutritional value of the breast milk of the Malakand district were determined. The fats and protein were determined using the recommended methods by the Association of Official Analytical Chemists (AOAC) and Ward method, respectively while the fatty acid profile was determined through GC-MS. Milk samples were analyzed for proximate composition and from the results the moisture content was $87.69 \%$, ash $0.29 \%$, fats $3.63 \%$, protein $0.94 \%$, and carbohydrate content ware $7.45 \%$. The average fatty acid profiles of milk showed that it is composed of saturated (SFA), monounsaturated (MUFA) and polyunsaturated fatty acid (PUFA) with a concentration of $38.41 \%, 29.59 \%$, and $14.70 \%$, respectively. In general, both proximate and fatty acid profiles were found slightly different compared to the contents of breast milk in developed countries which may be due to the difference in diet, environment, and socioeconomic status of women in Pakistan.
\end{abstract}

Keywords: Human milk, Proximate composition, Fatty acids profile, Nutritional value

\section{Introduction}

Breast milk is the first source of energy and diet for a newborn and is a complete diet in infancy. It is different in characteristics from other mammalian and formula milk full of antibodies providing early protection to the baby [1]. There is no better nutrition for healthy infants than human breast milk, in terms of safety, energy, and balance of essential ingredients. It provides nutrients that are necessary for the growth and brain development of infants. The breast fed infant has an optimal growth pattern which is different from other milk-fed infants, similarly, the composition of breast milk, like the presence of various nutrients, compounds, and hormones are co-related with the short and long-term growth pattern [2]. Human milk acts as a protective agent and protects the infant from various infection diseases [3, 4]. The composition of human milk varies from mother to mother and is also related to maternal nutrition [5]. The constituents of human milk having outside sources are affected by mother diets like proteins, vitamin B12, and iodine, while carbohydrates are made in the breast of lactating mothers and are not affected by diet [6]. Fatty acids content of human milk is greatly varied because some 
fatty acids come from mother stores and some are supplied from the diet $[5,7]$.

Carbohydrate contents of human milk provide $40 \%$ of the required energy and fat produces $50 \%$ of the total energy required for the baby. Human milk lipids contain mostly saturated (SFA) and monounsaturated fatty acids, (MUFA) accounting for more than $80 \%$ of fats. Oleic acid (cis-9-Octadecenoic acid, a monounsaturated omega- 9 fatty acid nearly $30 \%$ fatty acids on average) plays a similar role in energy production and may affect lipoprotein metabolism [8]. Human milk also contained polyunsaturated fatty acids (PUFAs) which protect the infant from various diseases [9]. The long-chain polyunsaturated fatty acids (LCPUFA), in particular, arachidonic acid $(5,8,11,14-$ Eicosatetraenoic acid, a polyunsaturated omega- 6 fatty acid) and docosahexanoic acid (DHA, C22:6n3, an omega-3 fatty acid) have been identified as the possible supporters of neurodevelopment [10].

Human milk is also a rich source of protein supplying amino acids and energy to the infant [1]. Human milk contains $\alpha$ lactalbumin and lactoferrin in the breast [1] which is the second abundant part of human milk protein. They are specie specific and the amount of lactoferrin increases in the milk with the decrease of iron content, thus making more iron available for the infant. Human milk also contains immunoglobulin, mostly secretory igG, igA, and igM. Their presence is specific and dependent upon the exposure of the mother to antigen [11].

The objective of the present study was to check the nutritional value and fatty acid profile of human milk, collected from the Malakand district of Khyber Pakhtunkhwa (KPK) Pakistan for the first time and compare these with the milk of the mothers from developed countries.
Material and Methods Samples Collection

Human milk samples were collected in triplicate, $20 \mathrm{~mL}$ each from lactating women of district Malakand, Khyber Pakhtunkhwa, Pakistan. Total ten (10) samples, two samples in each group were collected from volunteer women having different nutritional status and lactating period. The samples were brought in iceboxes to Pakistan Council for Scientific and Industrial Research (PCSIR) laboratories complex Peshawar for analysis. The samples were properly labeled and stored at $-20^{\circ} \mathrm{C}$ till analysis. Concentrations of all analytes are reported based on fresh weight as the mean of triplicate measurements for all samples.

\section{Proximate Analysis \\ Fat content}

For the determination of the fat content of the collected samples, the Gerber method was employed. $10 \mathrm{~mL}$ sulfuric acid was taken in a graduated tube and added $11 \mathrm{~mL}$ of milk then added $1 \mathrm{~mL}$ of amyl alcohol, mixed, and centrifuged at $12,000 \mathrm{rpm}$ for $5 \mathrm{~min}$. The reading was taken as:

\section{B-A}

Where

$\mathrm{B}$ : is the reading at the top of the fat column

$\mathrm{A}$ : is the reading at the bottom of the fat column

The difference in reading in the tube was the percent fat in the milk sample [12].

\section{Moisture Content}

Moisture content was determined through the thermogravimetric method. First, the crucible was heated in an oven at $102 \pm$ $2^{\circ} \mathrm{C}$ for $30 \mathrm{~min}$ and then cooled in a desiccator to room temperature. Weighed the empty crucible and then put $5 \mathrm{~mL}$ of milk sample in 
the crucible and weighed again. These were placed in the oven for $4 \mathrm{~h}$ at $110{ }^{\circ} \mathrm{C}$. After drying the crucibles were transferred into a desiccator and cooled to room temperature. The dried residue of the sample was weighed and moisture was calculated by subtracting the residue weight from the sample weight as $[13,14]$.

\section{Ash Content}

The ash content was determined by incineration at $\geq 550{ }^{\circ} \mathrm{C}$ in a furnace and weighing the residue. First, the crucible was heated in oven at $102 \pm 2{ }^{\circ} \mathrm{C}$ for $30 \mathrm{~min}$ and then placed in a desiccator till it reaches room temperature. Weighed the empty crucible and then put the milk sample in the crucible and weighed it again. The sample was first heated on a steam bath till dryness and then transferred to the furnace and burnt at $550{ }^{\circ} \mathrm{C}$ for $5 \mathrm{~h}$. The sample in the crucible was cooled to room temperature in a desiccator and calculated the ash content $[13,15]$.

\section{Protein Content}

The sample was thawed at room temperature and then $2 \mathrm{~mL}$ of milk sample was taken in a $50 \mathrm{~mL}$ falcon tube and centrifuged at $12,000 \mathrm{rpm}$ for $30 \mathrm{~min}$ at $4{ }^{\circ} \mathrm{C}$. The fat cake layer was removed from the top and mixed with one volume of water at room temperature. The lipid and protein layer were mixed and added one volume of distilled water, swirled for several minutes, and then centrifuged at $12,000 \mathrm{rpm}$ for $30 \mathrm{~min}$ at $4{ }^{\circ} \mathrm{C}$. This was repeated three times and all three aqueous phases were pooled [16]. For protein content determination the skimmed milk samples after removal of fats (discussed above) were added ethanol and water solution prepared in 2:1 ratio; well mixed and subjected to centrifugation at $12,000 \mathrm{rpm}$ for $30 \mathrm{~min}$ at $4{ }^{\circ} \mathrm{C}$. This was repeated three times and the supernatants of three precipitations were pooled. The precipitated protein was dried under reduced pressure and quantified gravimetrically [16].

\section{Carbohydrate Content}

The carbohydrate content of human milk was determined by subtracting the sum of fats, protein, moisture, and ash contents from 100 [13].

Carbohydrate Content $=100-\mathrm{A}-\mathrm{B}-\mathrm{C}-\mathrm{D}$

Where:

$\mathrm{A}=\%$ Fats content

$\mathrm{B}=\%$ Protein content

$\mathrm{C}=\%$ Moisture content

$\mathrm{D}=\%$ Ash content

\section{Determination of Milk Fatty acids}

The fatty acid contents of human milk were determined by GC-MS. Took $40 \mathrm{mg}$ of milk in a sealed cap test tube and added 1.5 $\mathrm{mL}$ sodium hydroxide $(0.5 \mathrm{M})$ solution in methanol. It was heated on boiling water for 5 $\mathrm{min}$; then cooled and $2.5 \mathrm{~mL} \mathrm{BF}_{3}$ solution in methanol $(10 \%)$ was added and heated again at boiling water for $30 \mathrm{~min}$. The solution was cooled, and $5 \mathrm{~mL}$ saturated sodium chloride solution and $1 \mathrm{~mL}$-hexane was added. Shake the solution vigorously and allowed to stand for $5 \mathrm{~min}$. The upper layer was extracted by a micropipette. The extraction was repeated once again with $1 \mathrm{~mL} n$-hexane. The $\mathrm{n}$-hexane layer was filtered through a membrane filter paper $(0.45 \mu \mathrm{m}) .1 \mu \mathrm{L}$ of the sample was injected into GC-MS for determination of fatty acid profile [13].

\section{Statistical Analysis}

For all analyses, data were reported as mean \pm standard deviation of triplicate measurements. The significant differences $(p$ $<0.05)$ within means were determined by one- 
way analysis of variance (ANOVA) and Tukey's honestly significant difference (HSD) test in the SPSS (Statistical Package for Social Sciences) Software Version 18 (IBM, New York, USA).

\section{Results and Discussion}

The various constituents of human milk have a vital role in the growth of the infant and the development of the immune and digestive systems [2]. The proximate composition of human milk varies with many factors, like the diet of a mother, mother health, lactation stage, and environment [2]. The proximate composition of milk has a direct correlation with the environment, health, and diet of the mother. All the human milk samples were analyzed to quantify their fats, protein, moisture, ash, and carbohydrate composition Table 1. The fat contents of the samples were found to be $3.63 \%$. Fat in human milk is responsible for nearly $50 \%$ of the energy of the infant but is extremely variable in content with the number of feeds, amount of milk in the breast, and the daily diet of the mother [17]. The amount of fat was less $(3.63 \%)$ than the fat content $(4.2 \%-4.5 \%)$ reported for developed countries. The probable reason is the consumption of the low-fat diet of the mothers in the study area. $[18,19]$. Proteins are manufactured in the breast and are the prime source of energy, and amino acids along with other physiological and biological functions in the human body. The protein content was found to be $0.94 \%$, which is in the acceptable range, though high protein content (1.3 to $2.3 \%$ ) is reported in some studies [18-20]. The Ash content in the human milk of the area was found to be $0.29 \%$ which is more than the reported one of 0.2 to $0.25 \%[18,19]$, the possible reason for the high ash content may be the presence of heavy metals and other inorganic contents in the water and food. The moisture content was $87.69 \%$ showing a normal value of moisture (Table 2).
Table 1. Proximate percent composition (\%) of human milk samples $(\mathbf{n}=\mathbf{1 0})$.

\begin{tabular}{cccccc}
\hline Samples & Fats & Protein & Moisture & Ash & $\begin{array}{c}\text { Carbohy } \\
\text { drates }\end{array}$ \\
\hline 40 Days & $3.71 \pm 0.23$ & $0.95 \pm 0.14$ & $87.70 \pm 3.33$ & $0.29 \pm 0.04$ & $7.35 \pm 1.32$ \\
50 Days & $3.74 \pm 0.26$ & $0.99 \pm 0.13$ & $87.65 \pm 3.23$ & $0.29 \pm 0.08$ & $7.33 \pm 1.42$ \\
2 Months & $3.46 \pm 0.24$ & $0.90 \pm 0.12$ & $87.80 \pm 3.42$ & $0.31 \pm 0.07$ & $7.53 \pm 1.23$ \\
4 Months & $3.60 \pm 0.28$ & $0.92 \pm 0.11$ & $87.72 \pm 2.74$ & $0.29 \pm 0.06$ & $7.47 \pm 1.46$ \\
6 Months & $3.65 \pm 0.22$ & $0.94 \pm 0.10$ & $87.60 \pm 3.25$ & $0.29 \pm 0.05$ & $7.52 \pm 1.22$ \\
Average & $3.63 \pm 0.25$ & $0.94 \pm 0.12$ & $87.69 \pm 3.19$ & $0.29 \pm 0.06$ & $7.45 \pm 1.33$ \\
\hline
\end{tabular}

Table 2. Comparison of proximate composition (\%) of human milk with reported data.

\begin{tabular}{cccccc}
\hline Fats & Protein & Moisture & Ash & $\begin{array}{c}\text { Carbohyd } \\
\text { rates }\end{array}$ & $\begin{array}{c}\text { Reported } \\
\text { data }\end{array}$ \\
\hline 3.63 & 0.94 & 87.69 & 0.29 & 7.45 & Present study \\
3.92 & 0.97 & - & - & 7.15 & Sweden [21] \\
$2.5-6.0$ & $0.83-1.30$ & $86.0-88.0$ & 0.2 & $6.3-8.1$ & USA [22] \\
4.0 & $0.8-1.58$ & 87 & & 6.8 & USA [23] \\
4.1 & 1.3 & 87.1 & - & 7.2 & $\begin{array}{c}\text { UK [24] } \\
\text { Common } \\
\text { Mature } \\
\text { human Milk } \\
{[25]}\end{array}$ \\
$3.0-5.0$ & $0.8-0.9$ & - & 0.2 & $6.9-7.2$ &
\end{tabular}

The average fatty acid compositions of human milk samples from the Malakand are given in Table 3. The samples contain $38.41 \%$ SFA, $29.59 \%$ MUFA, and $14.70 \%$ PUFA. The fatty acids compositions vary from person to person, as some fatty acids have the source in the diet while the others are synthesized in mammary glands. The human mammary gland is capable of synthesizing SFA primarily of 10 to 14 carbons chain. The fatty acids of more than 16 carbon chain are not synthesized in the mammary gland and must be obtained either from diet or mobilized from fat deposits of the body [26].

Data is not available on the fatty acid profile of human milk from Pakistan; therefore, efforts were made to compare the data with those of the fatty acid profile of Egyptian and American mothers. 
Pak. J. Anal. Environ. Chem. Vol. 21, No. 2 (2020)

Table 3. Fatty acid composition (\%) of human milk by GC-MS analysis.

\begin{tabular}{|c|c|c|c|c|c|c|}
\hline \multirow{2}{*}{ Fatty acids } & \multicolumn{5}{|c|}{ Human milk samples } & \multirow{2}{*}{ Mean \pm SE } \\
\hline & 40 days & 50 days & 2 months & 4 months & 6 months & \\
\hline Caproic acid $\left(\mathrm{C}_{6: 0}\right)$ & $0.07^{\text {a } 1)}$ & $0.07^{\mathrm{a}}$ & $0.11^{\mathrm{a}}$ & $0.11^{\mathrm{a}}$ & $0.09^{\mathrm{a}}$ & $0.09 \pm 0.01$ \\
\hline Caprylic acid $\left(\mathrm{C}_{8: 0}\right)$ & $0.18^{\mathrm{b}}$ & $0.19^{\mathrm{b}}$ & $0.11^{\mathrm{a}}$ & $0.34^{\mathrm{c}}$ & $0.09^{\mathrm{a}}$ & $0.18 \pm 0.36$ \\
\hline Capric acid $\left(\mathrm{C}_{10: 0}\right)$ & $1.23^{\mathrm{b}}$ & $1.22^{\mathrm{b}}$ & $0.95^{\mathrm{a}}$ & $2.34^{\mathrm{c}}$ & $1.01^{\mathrm{a}}$ & $1.35 \pm 0.21$ \\
\hline Undecylic acid $\left(\mathrm{C}_{11: 0}\right)$ & $0.01^{\mathrm{a}}$ & $0.03^{\mathrm{a}}$ & $0.02^{\mathrm{a}}$ & $0.10^{\mathrm{b}}$ & $0.02^{\mathrm{a}}$ & $0.04 \pm 0.01$ \\
\hline Lauric acid $\left(\mathrm{C}_{12: 0}\right)$ & $4.92^{\mathrm{b}}$ & $4.23^{\mathrm{b}}$ & $2.63^{\mathrm{a}}$ & $9.70^{\mathrm{d}}$ & $5.30^{\mathrm{c}}$ & $5.36 \pm 0.96$ \\
\hline Tridecylic acid $\left(\mathrm{C}_{13: 0}\right)$ & $0.02^{\mathrm{a}}$ & $0.04^{\mathrm{a}}$ & $0.04^{\mathrm{a}}$ & $0.20^{\mathrm{b}}$ & $0.05^{\mathrm{a}}$ & $0.07 \pm 0.03$ \\
\hline Myristic acid $\left(\mathrm{C}_{14: 0}\right)$ & $4.42^{\mathrm{a}}$ & $3.90^{\mathrm{a}}$ & $4.77^{\mathrm{a}}$ & $10.12^{\mathrm{c}}$ & $6.88^{\mathrm{b}}$ & $6.02 \pm 0.94$ \\
\hline Pentadecylic acid $\left(\mathrm{C}_{15: 0}\right)$ & $0.16^{\mathrm{a}}$ & $0.15^{\mathrm{a}}$ & $0.50^{\mathrm{c}}$ & $0.65^{\mathrm{c}}$ & $0.28^{\mathrm{b}}$ & $0.35 \pm 0.09$ \\
\hline Palmitic acid $\left(\mathrm{C}_{16: 0}\right)$ & $21.29^{\mathrm{b}}$ & $21.75^{\mathrm{b}}$ & $19.58^{\mathrm{b}}$ & $25.25^{\mathrm{c}}$ & $14.96^{\mathrm{a}}$ & $20.57 \pm 1.38$ \\
\hline Margaric acid $\left(\mathrm{C}_{17: 0}\right)$ & $0.21^{\mathrm{a}}$ & $0.15^{\mathrm{a}}$ & $0.42^{\mathrm{b}}$ & $0.64^{\mathrm{c}}$ & $0.20^{\mathrm{a}}$ & $0.32 \pm 0.08$ \\
\hline Stearic acid $\left(\mathrm{C}_{18: 0}\right)$ & $4.31^{\mathrm{c}}$ & $3.54^{\mathrm{b}}$ & $4.37^{\mathrm{c}}$ & $4.61^{\mathrm{c}}$ & $2.49^{\mathrm{a}}$ & $3.86 \pm 0.32$ \\
\hline Arachidic acid $\left(\mathrm{C}_{20: 0}\right)$ & $0.16^{\mathrm{b}}$ & $0.08^{\mathrm{a}}$ & $0.07^{\mathrm{a}}$ & $0.09^{\mathrm{a}}$ & $0.05^{\mathrm{a}}$ & $0.09 \pm 0.02$ \\
\hline Heneicosylic acid $\left(\mathrm{C}_{21: 0}\right)$ & $0.03^{\mathrm{a}}$ & $0.04^{\mathrm{a}}$ & $0.05^{\mathrm{a}}$ & $0.04^{\mathrm{a}}$ & $0.03^{\mathrm{a}}$ & $0.04 \pm 0.00$ \\
\hline Behenic acid $\left(\mathrm{C}_{22: 0}\right)$ & $0.08^{\mathrm{a}}$ & $0.07^{\mathrm{a}}$ & $0.08^{\mathrm{a}}$ & $0.09^{\mathrm{a}}$ & $0.08^{\mathrm{a}}$ & $0.08 \pm 0.00$ \\
\hline$\sum \mathrm{SFA}^{2)}$ & 37.09 & 35.46 & 33.70 & 54.28 & 31.53 & 38.41 \\
\hline Myristoleic acid $\left(\mathrm{C}_{14: 1 \mathrm{c}}\right)$ & $0.10^{\mathrm{a}}$ & $0.10^{\mathrm{a}}$ & $0.48^{\mathrm{b}}$ & $0.42^{\mathrm{b}}$ & $0.31^{\mathrm{b}}$ & $0.28 \pm 0.07$ \\
\hline Palmitoleic acid $\left(\mathrm{C}_{16: 1 \mathrm{l}}\right)$ & $2.70^{\mathrm{b}}$ & $3.44^{\mathrm{c}}$ & $2.55^{\mathrm{b}}$ & $3.75^{\mathrm{c}}$ & $1.82^{\mathrm{a}}$ & $2.85 \pm 0.28$ \\
\hline Heptadecanoic acid $\left(\mathrm{C}_{17: 1}\right)$ & $0.11^{\mathrm{a}}$ & $0.11^{\mathrm{a}}$ & $0.22^{\mathrm{b}}$ & $0.39^{c}$ & $0.12^{\mathrm{a}}$ & $0.19 \pm 0.04$ \\
\hline Oleic acid $\left(\mathrm{C}_{18: 1 \mathrm{c}}\right)$ & $33.47^{\mathrm{c}}$ & $31.45^{\mathrm{c}}$ & $23.16^{\mathrm{b}}$ & $22.31^{\mathrm{b}}$ & $15.67^{\mathrm{a}}$ & $25.21 \pm 2.71$ \\
\hline Gondoic acid $\left(\mathrm{C}_{21: 1}\right)$ & $0.20^{\mathrm{a}}$ & $0.19^{\mathrm{a}}$ & $0.18^{\mathrm{a}}$ & $0.19^{\mathrm{a}}$ & $0.19^{\mathrm{a}}$ & $0.19 \pm 0.04$ \\
\hline Elaidic acid $\left(\mathrm{C}_{18: \ln 9 \mathrm{t}}\right)$ & $0.87^{\mathrm{b}}$ & $1.09^{\mathrm{b}}$ & $0.96^{\mathrm{b}}$ & $0.91^{\mathrm{b}}$ & $0.50^{\mathrm{a}}$ & $0.87 \pm 0.04$ \\
\hline$\sum$ MUFA $^{3)}$ & 37.45 & 36.38 & 27.55 & 27.97 & 18.61 & 29.59 \\
\hline Linoleic acid $\left(\mathrm{C}_{18: 2 \mathrm{c}}\right)$ & $18.38^{\mathrm{c}}$ & $10.49^{\mathrm{b}}$ & $9.30^{\mathrm{ab}}$ & $15.39^{\mathrm{c}}$ & $8.48^{\mathrm{a}}$ & $12.81 \pm 1.63$ \\
\hline Eicosadienoic acid $\left(\mathrm{C}_{20: 2}\right)$ & $0.28^{\mathrm{b}}$ & $0.10^{\mathrm{a}}$ & $0.14^{\mathrm{a}}$ & $0.31^{\mathrm{b}}$ & $0.13^{\mathrm{a}}$ & $0.19 \pm 0.04$ \\
\hline Octadecadienoic acid $\left(\mathrm{C}_{18: 2 \mathrm{t}}\right)$ & $0.12^{\mathrm{b}}$ & $0.95^{\mathrm{d}}$ & $0.13^{\mathrm{b}}$ & $0.06^{\mathrm{a}}$ & $0.37^{\mathrm{c}}$ & $0.33 \pm 0.17$ \\
\hline Linolenic acid $\left(\mathrm{C}_{18: 3 \mathrm{n} 3}\right)$ & $0.72^{\mathrm{b}}$ & $0.62^{\mathrm{b}}$ & $0.51^{\mathrm{b}}$ & $1.06^{\mathrm{c}}$ & $0.36^{\mathrm{a}}$ & $0.65 \pm 0.10$ \\
\hline Di-homogamma linolenic acid $\left(\mathrm{C}_{20: 3 \mathrm{n} 6}\right)$ & $0.52^{\mathrm{c}}$ & $0.28^{\mathrm{b}}$ & $0.32^{\mathrm{b}}$ & $0.78^{\mathrm{d}}$ & $0.16^{\mathrm{a}}$ & $0.41 \pm 0.04$ \\
\hline Arachidonic acid $\left(\mathrm{C}_{20: 4 n 6}\right)$ & $0.64^{\mathrm{bc}}$ & $0.52^{\mathrm{b}}$ & $0.37^{\mathrm{ab}}$ & $0.85^{\mathrm{c}}$ & $0.25^{\mathrm{a}}$ & $0.53 \pm 0.54$ \\
\hline Cervonic acid $\left(\mathrm{C}_{22: 6 n 3}\right)$ & $0.19^{\mathrm{ab}}$ & $0.19^{\mathrm{ab}}$ & $0.15^{\mathrm{a}}$ & $0.25^{\mathrm{b}}$ & $0.13^{\mathrm{a}}$ & $0.18 \pm 0.18$ \\
\hline$\sum \mathrm{PUFA}^{4)}$ & 20.85 & 13.15 & 10.92 & 18.70 & 9.88 & 14.70 \\
\hline $\begin{array}{l}\sum \mathrm{n}-3^{5)} \\
\sum \mathrm{n}-6^{6)} \\
\text { Ratio n-3/n-6 } \\
\text { Unknown }\end{array}$ & & & & & & $\begin{array}{c}0.83 \\
0.94 \\
0.89 \\
17.30 \\
\end{array}$ \\
\hline $\begin{array}{ll}\text { 1) }{ }^{\mathrm{a}-\mathrm{c}} \text { Values with different superscript lett } \\
\text { 1. } & \sum \mathrm{SFA}=\mathrm{Sum} \text { of saturated fatty ac } \\
\text { 2. } & \sum \mathrm{MUFA}=\mathrm{Sum} \text { of monounsaturat } \\
\text { 3. } & \sum \mathrm{PUFA}=\text { sum of polyunsaturated } \\
\text { 4. } & \sum \mathrm{n}-3, \text { total omega-3 fatty acids. } \\
\text { 5. } & \sum \mathrm{n}-6, \text { total omega-6 fatty acids. }\end{array}$ & $\begin{array}{l}\text { a row dif } \\
\text { cid. } \\
\text { d. }\end{array}$ & nificantly & $.05)$ & & & \\
\hline
\end{tabular}


The Pakistani human milk contains $38.41 \%$ medium-chain SFA (capric, lauric, and myristic acids) which were found to be very high as compared to human milk from Egyptian and American origin (SFA of Egyptian milk was $19.8 \%$ and that of American women was $13.7 \%$ ). The difference may be due to the high intake of carbohydrate as an energy source by Pakistani mothers which reduces the intake of fats and increase the level of lauric acid and myristic acid in milk [27, 28]. Pakistani milk contains $12.81 \%$ linoleic acid was lower than Egyptian and American milk $(23.80 \%$ and $17.20 \%$, respectively). The unbalanced diet is the cause of the low amount of linoleic acid as linoleic acid has a total dietary origin $[29,30]$. The amount of palmitic acid in Pakistani milk was $25.25 \%$ which was higher than Egyptian and American human milk. The palmitic acid show an inverse relation with LCPUFA concentration and in Pakistani human milk the PUFA concentration was low, therefore the palmitic acid concentration was high [28]. The Oleic acid represented the largest percentage of the total analyzed fatty acids in all the Pakistani, Egyptian, and American human milk. The amount of oleic acid in Pakistani human milk was lower as compared to American human milk but comparable to Egyptian milk. The presence of oleic acid in human milk is related to intake of dietary saturated fats. The American women consuming libitium diet which contains a high amount of fats [31]. The USFA comprised $29.59 \%$ of the fatty acids in the milk of Pakistani women which shows the consumption of un-hydrogenated oils. The arachidonic acid and docosahexanoic acid in Pakistani human milk were normal and the level of arachidonic acid was high than docosahexanoic acid. Their normal level is necessary for the normal neural development of an infant.

\section{Conclusion}

The analysis of the human milk samples from the Malakand area showed that the nutrients present in these samples were in the same range as reported from other countries (Table 2). The ash and carbohydrate content were within the range but skewed towards the upper limit. This might be due to the quality of water and the nature of the diet of the area. The water is generally used directly from the wells in the subject area. The common diet of the people is locally grown vegetables. The difference in the concentration of the various fatty acids and other nutrients in Pakistani, Egyptian, and American milk may be due to differences in diet, region, environment, and socioeconomic status of women which affect the fatty acid composition of milk. The pattern shows a possibility of low fat and high carbohydrate diet of the mother in the area.

\section{Ethical Approval}

The study was approved by the Kohat University of Science \& Technology ethical committee.

\section{Conflict of Interest}

The author declares that they have no conflict of interest.

\section{Acknowledgment}

We are thankful to PCSIR Peshawar for their help and cooperation.

\section{References}

1. C. R. Martin, P.-R. Ling and G. L. Blackburn, Nutrients, 8 (2016) 279. doi.org/10.3390/nu8050279

2. M. V. Lind, A. Larnkjaer, C. Mølgaard and K. F. Michaelsen, in Recent 
Research in Nutrition and Growth, ed. K. B. Colombo J, Lampl M, Karger Publishers, Basel, Switzerland, 89 (2018) 63. doi: $10.1159 / 000486493$

3. P. Palmeira and M. Carneiro-Sampaio, Revista da Associação Médica Brasileira, 62 (2016) 584.

doi: 10.1590/1806-9282.62.06.584

4. C. G. Turin and T. J. Ochoa, Curr. Trop. Med. Rep., 1 (2014) 97.

doi: 10.1007/s40475-014-0015-x

5. F. Bravi, F. Wiens, A. Decarli, A. Dal Pont, C. Agostoni and M. Ferraroni, Am. J. Clin. Nutr., 104 (2016) 646. doi: 10.3945/ajcn.115.120881

6. A. L. Mudd A, Waworuntu R, Berg B, Donovan S and Dilger R Front. Young Minds, 5 (2017) 1. doi: 10.3389/frym.2017.00016

7. O. Ballard and A. L. Morrow, Pediatr. Clin. North. Am., 60 (2013) 49. doi: 10.1016/j.pcl.2012.10.002

8. N. J. Andreas, B. Kampmann and K. M. Le-Doare, Early Human Devel., 91 (2015) 629.

doi: 10.1016/j.earlhumdev.2015.08.013

9. G. J. F. S. González, S. F. O'Keefe, S. E. Duncan, E. McLean and S. R. Craig, J. Food Compos. Anal., 19 (2006) 720. doi.org/10.1016/i.jfca.2006.01.007

10. C. Agostoni, I. Brunetti and A. D. Marco, Curr. Pediatr. Rev., 1 (2005) 25. doi: 10.2174/1573396052953435

11. W. L. Hurley and P. K. Theil, Nutrients, 3 (2011) 442.

doi: 10.3390/nu3040442

12. D. H. Kleyn, J. M. Lynch, D. M. Barbano, M. J. Bloom and M. W. Mitchell, J. AOAC Int., 84 (2001) 1499. doi:10.1093/JAOAC/84.5.1499

13. AOAC, The Official Method of Analysis AOAC International Chapter 33, Boca Roton, 19th edn., (2012).
14. S. Rückold, K. H. Grobecker and H.-D. Isengard, Fresenius J. Anal. Chem., 368 (2000) 522.

doi: $10.1007 / \mathrm{s} 002160000511$

15. P. Schuck, Dolivet, A. and Jeantet, R. , in Analytical Methods for Food and Dairy Powders, ed. A. D. a. R. J. P. Schuck, (2012) 113. doi: 10.1002/9781118307397.ch6.

16. R. E. Ward, Open Glycosci., 2 (2009) 9. doi: 10.2174/1875398100902010009

17. J. C. K. Leon R. Mitoulas, David B. Cox, Robyn A. Owens, Jillian L. Sherriff and P. E. Hartmann British J. Nutr., 88 (2002) 29.

doi.org/10.1079/BJN2002579

18. P. Mcveagh, Pacific Health Dialog, 1 (1994) 43.

19. W. G. Hans-Dieter Belitz, Peter Schieberle, Food Chemistry, SpringerVerlag Berlin Heidelberg 4th edn., 2009.

20. I. S. R. Pauline and M. Emmett, Early Human Devel., 49 (1997) S7. doi.org/10.1016/S0378-3782(97)00051-0

21. K. F. Michaelsen, P. S. Larsen, B. L. Thomsen and G. Samuelson, Am. J. Clin. Nutr., 59 (1994) 600.

doi: 10.1093/ajcn/59.3.600

22. E. M. Miller, M. O. Aiello, M. Fujita, K. Hinde, L. Milligan and E. Quinn, Am. J. Human Biol., 25 (2013) 1.

doi: 10.1002/ajhb.22334.

23. M. F. Picciano, Pediatr. Clin. North Am., 48 (2001) 53.

doi.org/10.1016/S0031-3955(05)70285-6

24. P. M. Emmett and I. S. Rogers, Early Human Devel., 49 (1997) S7. doi.org/10.1016/S0378-3782(97)00051-0

25. R. Jenness, Seminars in Perinatolo., 3 (1979) 225.

26. M. W. Borschel, R. G. Elkin, A. Kirksey, J. A. Story, O. Galal, G. G. Harrison and N. W. Jerome, Am. J. Clin. Nutr., 44 (1986) 330. doi: 10.1093/ajen/44.3.330 
27. A. Jenkins, T. Markovic, A. Fleury and L. Campbell, Diabetologia, 40 (1997) 348.

doi: $10.1007 / \mathrm{s} 001250050686$

28. W. Read, P. G. Lutz and A. Tashjian, Am. J. Clin. Nutr., 17 (1965) 184. doi.org/10.1093/ajen/17.3.184

29. B. Koletzko, M. Mrotzek and H. Bremer, Am. J. Clin. Nutr., 47 (1988) 954.

doi.org/10.1093/ajen/47.6.954
30. H. A. Guthrie, M. F. Picciano and D. Sheehe, J. Pediat., 90 (1977) 39. doi: 10.1016/s0022-3476(77)80761-0

31. E. J. Livant, M. A. Wickwire, M. C. Craig-Schmidt, S. A. Faircloth and J. D. Weete, Am. J. Clin. Nutr., 39 (1984) 778.

doi: 10.1093/ajen/39.5.778 